\title{
Extensive reduction of surface UV radiation since 1750 in world's populated regions
}

\author{
M. M. Kvalevåg ${ }^{1}$, G. Myhre ${ }^{1,2}$, and C. E. Lund Myhre ${ }^{3}$ \\ ${ }^{1}$ Department of Geosciences, University of Oslo, P.B. 1022 Blindern, 0315 Oslo, Norway \\ ${ }^{2}$ Center for International Climate and Environmental Research - Oslo (CICERO), P.B. 1129 Blindern, 0318 Oslo, Norway \\ ${ }^{3}$ Norwegian Institute for Air Research, P.B. 100, 2027 Kjeller, Norway
}

Received: 9 March 2009 - Published in Atmos. Chem. Phys. Discuss.: 30 April 2009

Revised: 21 September 2009 - Accepted: 28 September 2009 - Published: 19 October 2009

\begin{abstract}
Human activity influences a wide range of components that affect the surface UV radiation levels, among them ozone at high latitudes. We calculate the effect of human-induced changes in the surface erythemally weighted ultra-violet radiation (UV-E) since 1750. We compare results from a radiative transfer model to surface UV-E radiation for year 2000 derived by satellite observations (from Total Ozone Mapping Spectroradiometer) and to ground based measurements at 14 sites. The model correlates well with the observations; the correlation coefficients are 0.97 and 0.98 for satellite and ground based measurements, respectively. In addition to the effect of changes in ozone, we also investigate the effect of changes in $\mathrm{SO}_{2}, \mathrm{NO}_{2}$, the direct and indirect effects of aerosols, albedo changes and aviation-induced contrails and cirrus. The results show an increase of surface UV-E in polar regions, most strongly in the Southern Hemisphere. Furthermore, our study also shows an extensive surface UV-E reduction over most land areas; a reduction up to $20 \%$ since 1750 is found in some industrialized regions. This reduction in UV-E over the industrial period is particularly large in highly populated regions.
\end{abstract}

\section{Introduction}

Ultra-violet (UV) radiation propagates through the Earth's atmosphere and is attenuated through absorption and scattering processes. Ozone in the stratosphere protects humans and all biological systems from harmful levels of radiation by absorbing UV radiation. Anthropogenic emissions of substances that destroy the stratospheric ozone have led to ozone depletion (Clerbaux et al., 2007). Some studies indicate that

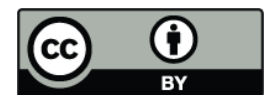

Correspondence to: G. Myhre (gunnar.myhre@cicero.uio.no) the increased amount of gases and aerosols in the troposphere from industrial emissions may counteract UV effects caused by the decrease in stratospheric ozone and thereby reduce the amount of UV radiation reaching the surface (Barnard et al., 2003; Liu et al., 1991; Sabziparvar et al., 1998). Trend studies of surface UV radiation levels are complex due to changes in many factors contributing to the surface UV levels. Additionally are long-term observations of ground-based UV levels limited; no data records longer than Belsk (1976) (Borkowski, 2008) and Norrkoping (1983) (Josefsson, 2006) are published, both showing a positive trend for the investigated period. An overview and further details on observed and reconstructed UV trends are discussed in the section below. We would like to emphasize that the observational records of UV are short, and only a few trends are considered as statistically significant according to the authors of previous publications of UV trends.

In this study we investigate the changes in erythemally weighted UV radiation (UV-E) since 1750 caused by anthropogenic changes in three gases (ozone, $\mathrm{NO}_{2}$, and $\mathrm{SO}_{2}$ ), the direct aerosol effect (sulphate, organic and black carbon from fossil fuel combustions and biomass burning), the cloud albedo effect due to aerosols, surface albedo changes due to deforestation and snow cover changes, and aviation-induced contrails and cirrus clouds, by using a global radiative transfer model. Our aim is to investigate the changes during the time period from 1750 to 2000 . The regional and temporal variations for the components differ over this period. The concentrations of air pollutants have been increasing due to anthropogenic emissions of aerosols and gases since the beginning of the industrial era, and thus influenced surface UV through centuries, while ozone depletion has been the most important factor for surface UV during the last decades.

Except for aviation-induced cirrus and the cloud albedo effect, we do not investigate the effects of possible changes in cloud distribution over the industrial era. The long term

Published by Copernicus Publications on behalf of the European Geosciences Union. 


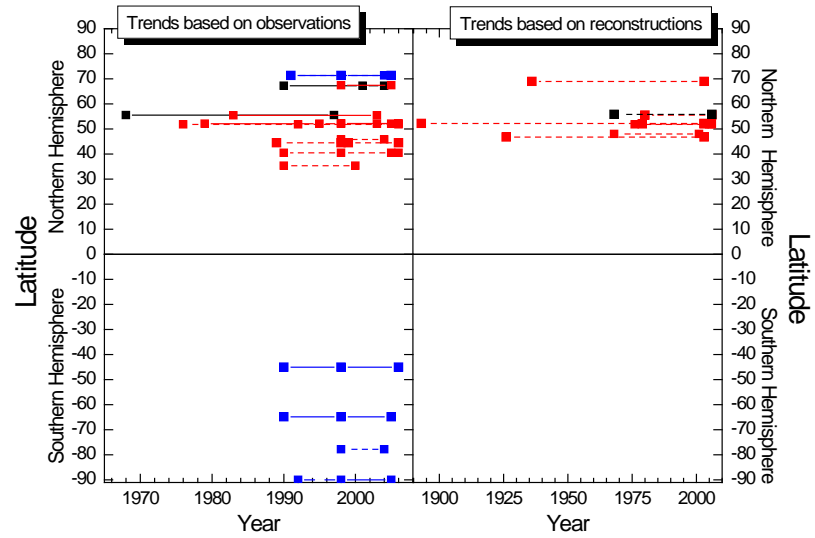

Fig. 1. Surface UV trends visualized for various latitudes and time periods. Red: Positive trends, blue: Negative trends and black: no trend. Solid line: significant trend according to the authors, dotted line: not given as a significant trend by the authors. The Figure is based on Tables 1 and 2 .

changes in the components in this study are treated consistent how their climate impacts are estimated in the Intergovernmental Panel on Climate Change Fourth Assessment Report (IPCC AR4) (Forster et al., 2007).

\section{Observed and reconstructed surface UV trends}

Routine spectral measurements of UV started in the late 1980's and thus few data series with long term data exist, but in recent years there are many studies on a shorter time scale. The possibility to retrieve statistical significant surface UV trends is dependent on the ozone and cloud variability at the particular site. Glandorf et al. (2005) showed that the UV data series has to be longer than 12-14 years to be able to retrieve significant trends. Table 1 provides an overview of recent available studies reporting long term trends in surface UV based on UV observations. Table 2 gives an overview of studies reporting trends based on reconstructed UV data.

Figure 1 provides an overview of the distribution of the positive and negative UV trends. The figure visualizes the trends with respect to latitudinal variations and time periods and is based on Tables 1-2. Included in the figure are studies presenting trends for the full year except for Troms $\varnothing$ $\left(69.4^{\circ} \mathrm{N}\right)$, which is the only site included in Table 1 with trends only for the spring months. The trends reported in the observational studies shown in Fig. 1 cover different time periods with most UV measurements starting in the beginning of 1990 and last for less than two decades.

The published UV-trends demonstrate a relatively clear tendency; At the Northern Hemisphere the UV surface doses have increased from the mid-1970s. UV observations from 11 different sites spanning from $35-71^{\circ} \mathrm{N}$ indicate an increase in the surface UV radiation the last two decades (Bais et al., 2007; McKenzie et al., 2007). Barrow and Toronto are exceptions; these are the only sites with negative trends for certain periods and seasons. A few studies report that there were no trends in the UV surface doses. Trends based on reconstruction of UV radiation support the trends based on the direct observations and are all positive for the investigated periods. The situation is different for the Southern Hemisphere (SH); there are fewer studies reporting trends and the four sites with published results show a negative trend with one exception. No reconstructed UV time series are included for this region.

\section{Method}

Global simulations of UV changes at the surface are calculated using a radiative transfer model (Myhre et al., 2002) which contains the discrete ordinate radiative transfer (DISORT) algorithm (Stamnes et al., 1988). The calculations are performed with a five nanometer $(\mathrm{nm})$ spectral resolution in the UVB (280-320 nm) and UVA (320-400 nm) regions, and thereafter integrated over the two wavelength intervals. The extinction at each wavelength is calculated and integrated into the $5 \mathrm{~nm}$ resolution. Test runs show that there is $1 \%$ difference between UV irradiances at the surface calculated at each wavelength compared to the $5 \mathrm{~nm}$ spectral resolution. We use the CIE-weights which relate UV radiation to human skin damages (McKinlay and Diffey, 1987), thus it is called erythemally UV radiation (UV-E). The action spectrum including the CIE-weights for UV-E radiation is equal to one for wavelengths less than $298 \mathrm{~nm}$ and decreases towards zero for longer wavelengths. After the UV irradiance is calculated by the model at the $5 \mathrm{~nm}$ resolution, we multiply with the CIE-weight function at each fifth wavelength to obtain the UV-E irradiance.

The model uses meteorological data for temperature and cloud cover from the European Center for Medium range Weather Forecasting (ECMWF) for the year 2000. The spatial resolution used in the radiative transfer calculations is T42 (approximately $3^{\circ} \times 3^{\circ}$ ) with 40 vertical layers. Calculations are done with a diurnal time step of three hours for monthly mean data (daily for indirect aerosol effect) and thereafter averaged into annual means. Calculations for the year 2000 and pre-industrial (1750) state of gases, aerosols, and albedo are performed, but with identical meteorological conditions (including clouds) making it possible to study only the investigated mechanisms. The aerosol and gas concentrations for present and pre-industrial times are taken from a global chemistry transport model (Oslo-CTM2) used in global model intercomparison exercises (Gauss et al., 2006; Schulz et al., 2006; Textor et al.,2006). Note here that we focus on changes between 1750 and 2000, and most components do not have a linear change over this time period, e.g. stratospheric ozone has been decreasing particularly in the last three decades whereas tropospheric ozone has 
Table 1. Overview of recent published trends in surface UV based on long term observations of surface UV.

\begin{tabular}{|c|c|c|c|c|c|c|}
\hline Location & Lattitude & $\begin{array}{r}\text { Trend/ } \\
\text { decade }^{\mathrm{a}}\end{array}$ & Period & Sig. ${ }^{b}$ & Spectral region & Reference \\
\hline South Pole & $90.0^{\circ} \mathrm{S}$ & $\begin{array}{r}-14.7^{\mathrm{cd}} \\
-34.6\end{array}$ & $\begin{array}{l}1992-2005 \\
1998-2005\end{array}$ & $\begin{array}{l}\text { No } \\
\text { Yes }\end{array}$ & $\begin{array}{l}\text { UV-E } \\
\text { UV-E }\end{array}$ & $\begin{array}{l}\text { McKenzie et al. (2007) } \\
\text { Bais et al. (2007) }\end{array}$ \\
\hline McMurdo & $77.8^{\circ} \mathrm{S}$ & $\begin{array}{l}+5.5^{\mathrm{c}} \\
-25.7\end{array}$ & $\begin{array}{l}1990-2004 \\
1998-2004\end{array}$ & $\begin{array}{l}\text { No } \\
\text { No }\end{array}$ & $\begin{array}{l}\text { UV-E } \\
\text { UV-E }\end{array}$ & $\begin{array}{l}\text { McKenzie et al. (2007) } \\
\text { Bais et al. (2007) }\end{array}$ \\
\hline Palmer & $64.8^{\circ} \mathrm{S}$ & $\begin{array}{r}-2.7^{\mathrm{c}} \\
-8.4 \\
-15.5\end{array}$ & $\begin{array}{l}1990-2005 \\
1990-2005 \\
1998-2005\end{array}$ & $\begin{array}{l}\text { No } \\
\text { Yes } \\
\text { Yes }\end{array}$ & $\begin{array}{l}\text { UV-E } \\
\text { UV-E } \\
\text { UV-E }\end{array}$ & $\begin{array}{l}\text { McKenzie et al. (2007) } \\
\text { Bais et al. (2007) } \\
\text { Bais et al. (2007) }\end{array}$ \\
\hline Lauder & $45.0^{\circ} \mathrm{S}$ & $\begin{array}{r}-9.5^{\mathrm{c} e} \\
-8.4^{\mathrm{e}} \\
-14.6\end{array}$ & $\begin{array}{l}1990-2005 \\
1990-2006 \\
1998-2006\end{array}$ & $\begin{array}{l}\text { Yes } \\
\text { Yes } \\
\text { Yes }\end{array}$ & $\begin{array}{l}\text { UV-E } \\
\text { UV-E } \\
\text { UV-E }\end{array}$ & $\begin{array}{l}\text { McKenzie et al. (2007) } \\
\text { Bais et al. (2007) } \\
\text { Bais et al. (2007) }\end{array}$ \\
\hline Hiratsuka & $35.4^{\circ} \mathrm{N}$ & $+15.7^{\mathrm{f}}$ & 1990-2000 & No & UV-B, 2 bands & Sasaki et al. (2002) \\
\hline Thessaloniki & $40.5^{\circ} \mathrm{N}$ & $\begin{array}{r}+2.6^{\mathrm{c}} \\
+1.5^{\mathrm{g}} \\
\text { Positive }^{\mathrm{h}}\end{array}$ & $\begin{array}{l}1990-2005 \\
1998-2006 \\
1990-2001\end{array}$ & $\begin{array}{l}\text { No } \\
\text { No } \\
\text { No }\end{array}$ & $\begin{array}{c}\text { UV-E } \\
\text { UV-E } \\
\text { Spectral UV }\end{array}$ & $\begin{array}{l}\text { McKenzie et al. (2007) } \\
\text { Bais et al. (2007) } \\
\text { Glandorf et al. (2005) }\end{array}$ \\
\hline Toronto & $43.8^{\circ} \mathrm{N}$ & $\begin{array}{r}\text { Positive }{ }^{\mathrm{i}} \\
-1.5^{\mathrm{c}} \\
+1.5\end{array}$ & $\begin{array}{l}1989-1999 \\
1989-2006 \\
1998-2006\end{array}$ & $\begin{array}{l}- \\
\text { No } \\
\text { No }\end{array}$ & $\begin{array}{l}\text { UV-B } \\
\text { UV-E } \\
\text { UV-E }\end{array}$ & $\begin{array}{l}\text { Fioletov et al. (2001) } \\
\text { McKenzie et al. (2007) } \\
\text { Bais et al. (2007) }\end{array}$ \\
\hline Ispra & $45.8^{\circ} \mathrm{N}$ & $\begin{array}{r}+1.4^{\mathrm{c}} \\
+9.1\end{array}$ & $\begin{array}{l}1992-2004 \\
1998-2005\end{array}$ & $\begin{array}{l}\text { No } \\
\text { No }\end{array}$ & $\begin{array}{l}\text { UV-E } \\
\text { UV-E }\end{array}$ & $\begin{array}{l}\text { McKenzie et al. (2007) } \\
\text { Bais et al. (2007) }\end{array}$ \\
\hline Belsk & $51.8^{\circ} \mathrm{N}$ & $\begin{array}{l}\sim+4 \\
+2.3\end{array}$ & $\begin{array}{l}1992-2004 \\
1976-2006\end{array}$ & $\begin{array}{l}\text { No } \\
\text { No }\end{array}$ & $\begin{array}{l}\text { UV-E } \\
\text { UV-E }\end{array}$ & $\begin{array}{l}\text { Jaroslawski and Krzyscin (2005) } \\
\text { Borkowski (2008) }\end{array}$ \\
\hline Bilthoven & $52.1^{\circ} \mathrm{N}$ & $\begin{array}{r}+14.2^{\mathrm{c}} \\
+16.9 \\
+5.5\end{array}$ & $\begin{array}{l}1996-2005 \\
1998-2006 \\
1979-2003\end{array}$ & $\begin{array}{l}\text { No } \\
\text { Yes } \\
\text { Yes }\end{array}$ & $\begin{array}{l}\text { UV-E } \\
\text { UV-E } \\
\text { UV-E }\end{array}$ & $\begin{array}{l}\text { McKenzie et al. (2007) } \\
\text { Bais et al. (2007) } \\
\text { den Outer et al. (2005) }\end{array}$ \\
\hline Lindenberg & $52.2^{\circ} \mathrm{N}$ & $\begin{array}{l}+1.1^{\mathrm{c}} \\
+14.0\end{array}$ & $\begin{array}{l}1995-2005 \\
1998-2006\end{array}$ & $\begin{array}{l}\text { No } \\
\text { Yes }\end{array}$ & $\begin{array}{l}\text { UV-E } \\
\text { UV-E }\end{array}$ & $\begin{array}{l}\text { McKenzie et al. (2007) } \\
\text { Bais et al. (2007) }\end{array}$ \\
\hline Moscow & $55.7^{\circ} \mathrm{N}$ & $\begin{array}{r}\text { No trend } \\
\text { No trend }{ }^{j}\end{array}$ & $\begin{array}{l}1968-1997 \\
1968-1997\end{array}$ & - & $\begin{array}{c}\text { UV-E } \\
\text { UV irr. } 380 \mathrm{~nm}\end{array}$ & $\begin{array}{l}\text { Chubarova (2000) } \\
\text { Chubarova (2000) }\end{array}$ \\
\hline Norrköping & $58.6^{\circ} \mathrm{N}$ & $+5.2^{\mathrm{k}}$ & 1983-2003 & Yes & UV-E & Josefsson (2006) \\
\hline Sodankylä & $67.3^{\circ} \mathrm{N}$ & $\begin{array}{r}+9.2^{\mathrm{c}} \\
+7.3 \\
\text { No trend }^{\mathrm{h}} \\
\text { No trend }^{\mathrm{l}}\end{array}$ & $\begin{array}{l}1990-2004 \\
1998-2005 \\
1990-2004 \\
1990-2001\end{array}$ & $\begin{array}{l}\text { Yes } \\
\text { No } \\
- \\
-\end{array}$ & $\begin{array}{c}\text { UV-E } \\
\text { UV-E } \\
\text { Spectral UV } \\
\text { Spectral UV }\end{array}$ & $\begin{array}{l}\text { McKenzie et al. (2007) } \\
\text { Bais et al. (2007) } \\
\text { Glandorf et al. (2005) } \\
\text { Lakkala et al. (2003) }\end{array}$ \\
\hline Barrow & $71.3^{\circ} \mathrm{N}$ & $\begin{array}{l}+3.8^{\mathrm{c}} \\
-4.4 \\
-2.3\end{array}$ & $\begin{array}{l}1991-2004 \\
1991-2005 \\
1998-2005\end{array}$ & $\begin{array}{l}\text { No } \\
\text { Yes } \\
\text { No }\end{array}$ & $\begin{array}{l}\text { UV-E } \\
\text { UV-E } \\
\text { UV-E }\end{array}$ & $\begin{array}{l}\text { McKenzie et al. (2007) } \\
\text { Bais et al. (2007) } \\
\text { Bais et al. (2007) }\end{array}$ \\
\hline
\end{tabular}

a The trends are based on full years with observations. If only a part of the year is used, this is indicated as a footnote below. There are various time resolutions used as a basis for trends in the various studies. These are treated equally (monthly mean, daily mean, noon observations) in the Table. The units are given in percent $(\%)$.

$\mathrm{b}$ The significance given is according to criteria defined by the authors of the respective publications.

c Only 3 summer months are used in the calculation of the trends.

$\mathrm{d}$ Wrong sign is given in the paper for this site. This is confirmed by personal communication with the author.

e Observations were performed only under fair weather conditions up to 1994 and no data under wet weather in the period 1994-1998.

f The changes observed are not significant except for the winter months.

g It should be noted that there was a strong upward trend during 1990s for the bands with no ozone absorption. The authors attributed these changes to aerosol changes as AOD has decreased considerable in the same period.

$\mathrm{h}$ The analysis is based on spectral UV measurements $(290-330 \mathrm{~nm}$, resolution $0.5 \mathrm{~nm})$. The trend is mainly positive for the Thessaloniki site, but is partly dependant on wavelength and partly dependant on solar zenith angle.

${ }^{\mathrm{i}}$ The trend is given for every wavelength, and is positive for all UV-B wavelengths.

$\mathrm{j}$ Months included in the analysis were only May-September. A decreasing trend was observed until $\sim 1980$ and then an increase, but no overall trend was found.

${ }^{\mathrm{k}}$ Significant positive trends for all seasons.

${ }^{1}$ Spectral UV observations $(290-0335 \mathrm{~nm}$, resolution $0.5 \mathrm{~nm})$. The trend is dependent on the wavelength. 
Table 2. Overview of recent published modeled trends in surface UV based on reconstructed UV time series.

\begin{tabular}{|c|c|c|c|c|c|c|}
\hline Location & Location & $\begin{array}{c}\text { Trend/ } \\
\text { decade }^{\mathrm{a}}\end{array}$ & Period & Sig. ${ }^{b}$ & Spectral region & Reference \\
\hline Davos & $46.8^{\circ} \mathrm{N}$ & Positive $^{c}$ & $1926-2003$ & - & UV-E & Lindfors and Vuilleumier (2005) \\
\hline Hohenpeissenberg & $47.8^{\circ} \mathrm{N}$ & $+2.0^{\mathrm{d}}$ & $1968-2001$ & No & UV-E & Trepte and Winkler (2004) \\
\hline Hradec Kralove & $50.1^{\circ} \mathrm{N}$ & Not given ${ }^{\mathrm{e}}$ & 1964-2001 & - & UV-B & Krzyscin et al. (2004) \\
\hline Bilthoven & $52.1^{\circ} \mathrm{N}$ & $+5.5^{f}$ & $1979-2003$ & - & UV-E & den Outer et al. (2005) \\
\hline Potsdam & $52.2^{\circ} \mathrm{N}$ & $\begin{array}{l}\text { Not given } \\
\text { Not given }\end{array}$ & $\begin{array}{l}1893-2002 \\
1893-2003\end{array}$ & $\begin{array}{l}\text { No } \\
\text { No }\end{array}$ & $\begin{array}{l}\text { UV-A, B, UV-E } \\
\text { UV-E, UV-A }\end{array}$ & $\begin{array}{l}\text { Junk et al. (2007) } \\
\text { Feister et al. (2008) }\end{array}$ \\
\hline Belsk & $52.5^{\circ} \mathrm{N}$ & $\begin{array}{c}+2.3 \\
\text { Not given }\end{array}$ & $\begin{array}{l}1976-2006 \\
1966-2001\end{array}$ & & $\begin{array}{l}\text { UV-E } \\
\text { UV-B }\end{array}$ & $\begin{array}{l}\text { Borkowski (2008) } \\
\text { Krzyscin et al. (2004) }\end{array}$ \\
\hline Moscow & $55.5^{\circ} \mathrm{N}$ & $\begin{array}{c}+6.0 \\
0^{\mathrm{i}}\end{array}$ & $\begin{array}{l}1968-2006 \\
1968-2006\end{array}$ & - & $\begin{array}{c}\text { UV-E } \\
\text { UV irr. Integral }\end{array}$ & $\begin{array}{l}\text { Chubarova (2008) } \\
\text { Chubarova (2008) }\end{array}$ \\
\hline Toravere & $58.2^{\circ} \mathrm{N}$ & Not given ${ }^{\mathrm{e}}$ & $1967-2001$ & & UV-B & Krzyscin et al. (2004) \\
\hline Troms $\varnothing$ & $69.4^{\circ} \mathrm{N}$ & $+2.8^{\mathrm{j}}$ & $1936-2003$ & - & UV-B & Engelsen et al. (2004) \\
\hline
\end{tabular}

a The trends are based on full years with observations. If only a part of the year is used, this is indicated as a footnote below. There are various time resolutions used as a basis for trends in the various studies. These are treated equally (monthly mean, daily mean, noon observations) in the table. The units are given in percent (\%).

$\mathrm{b}$ The significance given is according to criteria defined by the authors of the respective publications.

${ }^{\mathrm{c}}$ High values in 1940s, early 1960s, and an increase since 1985 of $~ 5 \%$ relative to 1940-1969. Aerosols are neglected in the model.

$\mathrm{d} 2 \%$ per decade is the average trend for the months Mar-Oct. The trend was significant for 2 months, and further the trend was negative for September and October. Observations of aerosols are not a part of the input to the model, and are not included in the analysis.

${ }^{\mathrm{e}}$ No trend for the whole period is given. The study includes only the months Apr-Sep. There is a general description of variation in UV-B with low values at the end of 1970s, and increase after this point. Information on aerosol variations are excluded in the model, and a constant $\mathrm{AOD}=0.25$ is used (annual average of Cimel in Belsk, Toravere, Potsdam).

$\mathrm{f}$ The clear sky trend was found to be +3.1 per decade. Information on aerosol variations is excluded in the model. A constant AOD, and Ångström parameter is used.

g No trend for the whole period is given but results based on the annual irradiation for various periods show: 1893-1935: Decrease, 19401980: Slight decrease, 1990-2002: Slight increase. Direct information of aerosols is not included in the model.

h No trend for the whole period is given, but it seems positive from the figures. Results for the various periods is as follows: $\sim 1900-1930$ : Increase, 1930-1945: Decrease, 1960-1980: Decrease, 1985-2003: Increase. Direct information of aerosols is not included in the model.

${ }^{\mathrm{i}}$ For the UV irradiance integral $300-380 \mathrm{~nm}$, no trend for the full period, but large and positive trend since $\sim 1980$.

$\mathrm{j}$ The study includes only the months Mar-May. The trends are as follows: $+4.5 \%$ (March), $+2.8 \%$ (April), $+1.3 \%$ (May). UV-A and PAR are unaffected of ozone absorption and show smaller trends in March and April, but similar in May.

had an increase over the whole time period. Also regional changes in some components occur, e.g. $\mathrm{SO}_{2}$ emission reductions over Europe since mid 1980s, but a strong increase over Asia. Additional simulations with monthly ozone concentrations provided by the Total Ozone Mapping Spectrometer (TOMS) are used for the total ozone columns for year 2000 in the model. Model results including TOMS ozone are used for comparison with observed surface UV-E radiation.

The ozone changes from Oslo CTM2 are in the midrange of the human induced ozone modifications simulated in a multi-model comparison (Gauss et al., 2006), both with respect to stratospheric and tropospheric ozone changes. Anthropogenic sulphate and carbonaceous aerosol changes (black carbon and organic carbon) are in the middle of a multi-model comparison (Schulz et al., 2006) with respect to anthropogenic aerosol fraction and radiative forcing of the direct aerosol effect. Natural background aerosols of sea salt, mineral dust, sulphate, and carbonaceous aerosols are included in the radiative transfer simulation for both year 1750 and 2000. The radiative forcing estimates of the direct aerosol effect (Schulz et al., 2006) and ozone (Gauss et al., 2006) were central in the IPCC AR4 estimates of these radiative forcings (Forster et al., 2007). Thus the Oslo CTM2 changes in ozone and aerosols represent the current state of knowledge of anthropogenic changes in these components. Sources for refractive indexes and hygroscopic growth 
Table 3. Refractive indexes and hygroscopic growth information for sulphate, black carbon, organic carbon and biomass burning aerosols.

\begin{tabular}{|c|c|c|c|c|}
\hline & Sulphate & Black carbon & Organic carbon & Biomass burning \\
\hline $\begin{array}{l}\text { Refractive } \\
\text { Index }\end{array}$ & Toon et al. (1976) & WCP (1986) & Similar to sulphate & $\begin{array}{l}\text { Based on SAFARI- } \\
2000 \text { results, } \\
\text { Haywood et al. } \\
\text { (2003) and Myhre } \\
\text { et al. (2003) }\end{array}$ \\
\hline $\begin{array}{l}\text { Hygroscopic } \\
\text { growth }\end{array}$ & Fitzgerald (1975) & No & Peng et al. (2001) & No \\
\hline
\end{tabular}

information for sulphate, black carbon from fossil fuel, organic carbon from fossil fuel and biomass burning aerosols are shown in Table 3. Aerosol optical properties are calculated with Mie theory based on aerosol size distribution and the source of refractive indexes as in Myhre et al. (2007). We assume pure scattering aerosol for OC from fossil fuel. Measurements of OC show that the absorption in the UV is quite variable from some components having pure scattering to other compounds having rather strong absorption in the UV region (Barnard et al., 2008; Dinar et al., 2007; Kanakidou et al., 2005; Kirchstetter et al., 2004; Martins, 2009; Myhre and Nielsen, 2004; Sun, 2007). We assume internally mixing for aerosols from biomass burning and thus OC and BC aerosols from this source have the same optical properties. This standard way of calculating the aerosol optical properties has been extended with calculations for each wavelength in the UV spectrum. For the indirect aerosol effect, we have considered all hydrophilic aerosols, including sub size sea salt and secondary organic aerosols and used the method of calculating effective radius for droplets in water clouds as in Quaas et al. $(2005 ;$ 2006). This method is based on the relation of the aerosol abundance and cloud droplet number concentration as retrieved by MODIS satellite data, and further their impact on the cloud optical properties. The treatment of the cloud albedo effect is consistent with the radiative forcing in the IPCC AR4 (Forster et al., 2007). Calculations of radiative effects caused by aviation contain relationship of air traffic data and the radiative forcing (Myhre and Stordal, 2001) and are performed as in Kvalevåg and Myhre (2007). The contrail cover from Myhre and Stordal (2001) is updated with the increased aircraft activity reported by Sausen et al. (2005). Information of aviation induced cirrus cover is based on the increase found in Stordal et al. (2005) and related that to the updated contrail cover described above. Anthropogenic vegetation changes since 1750 (Ramankutty and Foley, 1999) and MODIS surface albedo values at short wavelengths (Myhre et al., 2005) are included to calculate the UV-E changes due to surface albedo changes by land use. Two climate simulations with the NCAR Community Atmosphere Model CAM3 (Collins et al., 2006) are performed with present and pre industrial
$\mathrm{CO}_{2}$ concentrations to derive the snow cover change included in the radiative transfer model. Snow cover is calculated from the snow depth produced by the two climate simulations. The impact of snow on surface albedo depends on the underlying vegetation types. The albedo in snow covered regions is estimated using the surface albedo for snow-free vegetation, snow-covered vegetation, and snow depth (Betts, 2000; Myhre et al., 2005).

\section{Model comparisons with observations}

Observed monthly UV-E doses for the year 2000 are provided from fourteen sites worldwide and compared to the estimated UV-E doses calculated by the radiative transfer model. UV measurements from the ground based instruments were obtained from the World Ozone and Ultraviolet Radiation Data Centre (WOUDC) and the Norwegian institute for Air Research (NILU). Details about the various instruments and sites are available in WOUDC (http: //www.woudc.org/) except for the data from the Norwegian sites. The sites Oslo, Bergen, and Trondheim are all below $100 \mathrm{~m}$ a.s.l. and the instruments at Andøya and Ny-Ålesund are located around $400 \mathrm{~m}$ a.s.l. The instrument used at these sites is GUV-511 which is a multichannel filter instrument. Figure 2 compares ground based measurements and satellite retrieved surface UV-E radiation with the model estimates. The model (red line) correlates well $\left(r^{2}=0.98\right)$ with the observations (black line), reproducing peaks and seasonal variation, but the model tends to underestimate the UV-E doses during summertime at a few stations. This is caused by slightly too high ozone concentrations in the model during summer at low latitudes. This has been corrected for by the use of ozone data from the Total Ozone Mapping Spectrometer (TOMS). TOMS global daily UV-E doses from year 2000 are averaged into monthly ozone fields and the TOMS data are used in refined calculations to modify the ozone column used in the radiative transfer model. A ratio between TOMS ozone and the model is calculated from the total ozone column (in Dobson Unit, DU) and we assume no change in the ozone profiles and only a change in the ozone column (Eq. 1). 

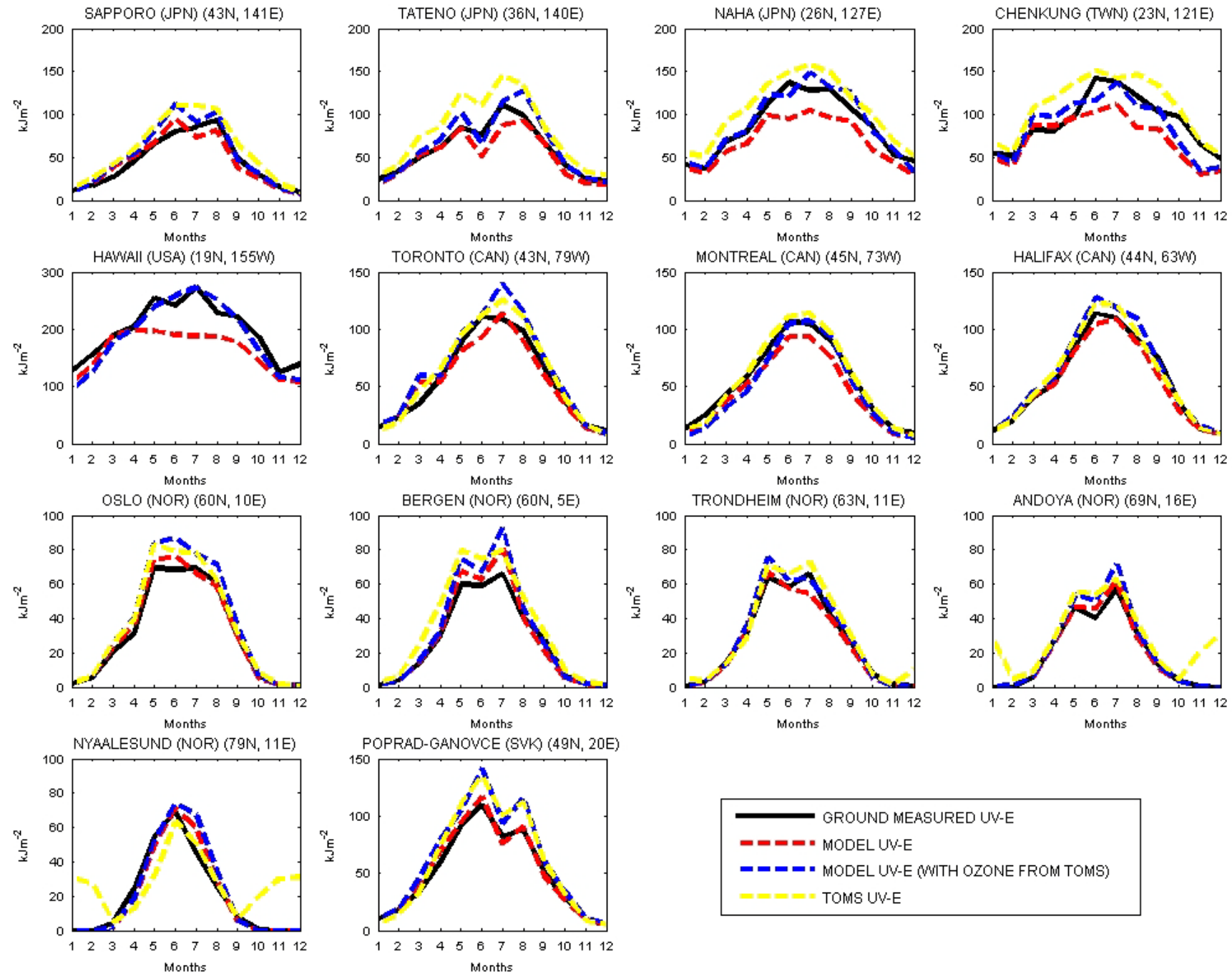

Fig. 2. Monthly surface UV-E doses at 14 sites for year 2000. Black: ground based measurements, red: model, blue: model including ozone data from TOMS, and yellow: TOMS surface UV-E retrieval. The UV observations from nine sites were obtained from the World Ozone and Ultraviolet Radiation Data Centre (WOUDC). The Norwegian institute for Air Research hosts the five Norwegian UV observations.

The ratio is then multiplied to the ozone concentration at each level in the model (Eq. 2).

$\sigma=\frac{\mathrm{O}_{3}(\mathrm{DU})_{\text {TOMS }}}{\mathrm{O}_{3}(\mathrm{DU})_{\text {model }}}$

$\mathrm{O}_{3}(\mathrm{Z})_{\text {model }_{\text {modified }}}=\sigma \mathrm{O}_{3}(\mathrm{Z})_{\text {model }}$

The blue curves in Fig. 2 show the model results where the total ozone column is in agreement with observations from TOMS. For the low latitude stations (Sapporo, Tateno, Naha, Chenkung and Hawaii) the model estimated UV-E doses are improved and show better agreement with the ground based measurements, yet the correlation coefficient remains at 0.98 . The reproduced seasonal cycle constitutes a dominating part of the correlation between the observations and the model, but other additional factors are important in order to calculate reasonable UV radiation at the surface. UV absorbing gases and aerosols as well as scattering aerosols contribute to differences between surface UV radiation measured by ground based instruments and UV radiation either retrieved by the satellite or calculated by the model. In addition, we have compared the model UV-E doses to satellite retrieved surface UV-E doses from TOMS. The daily maps of global erythemally UV at the surface from TOMS are based on backscattered irradiation measured by TOMS and radiative transfer models calculations (Herman et al., 1999; Krotkov et al., 1998, 2001). TOMS retrieved surface UV-E doses are included for the respective sites in Fig. 2 (yellow line). Notice the overestimation of the UV-E in the TOMS retrieval 

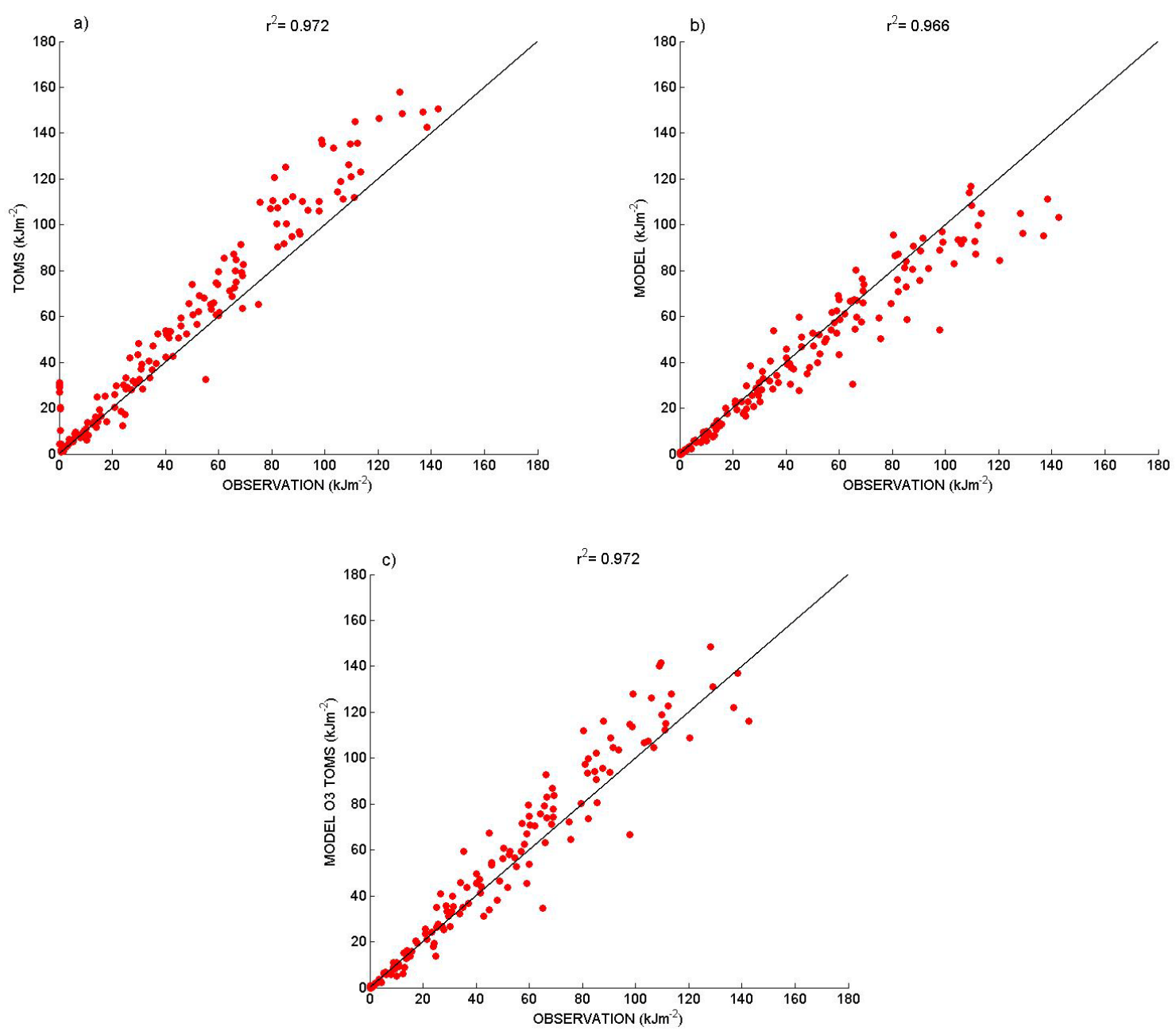

Fig. 3. Correlations of monthly mean surface UV-E doses between ground based measurements from 13 sites (not including Hawaii) and (a) TOMS surface UV-E retrieval, (b) the model, and (c) the model including ozone values from TOMS. Correlation coefficients $\left(r^{2}\right)$ are shown on top of each panel.

compared to the ground measurements at a few sites, particularly at low latitudes. This overestimation is consistent with earlier comparison studies between ground based measurements and TOMS (Fioletov et al., 2002; Kazantzidis et al., 2006; McKenzie et al., 2001). The satellite retrieved UV$\mathrm{E}$ data at Hawaii is removed because the special condition with high altitude of the site is not captured in the satellite retrieved UV-E.

Figure 3 shows scatter plots and correlation coefficients for the monthly mean surface UV-E from ground measurements at all sites (excluding Hawaii) versus (a) the TOMS retrieval, (b) the model, and (c) the model including TOMS ozone data. The model (especially when including TOMS ozone data) compares at least as good as the TOMS UVE satellite retrieval to the surface measurements. The geographical distributions of surface annual mean UV-E doses for year 2000 are shown in Fig. 4 for (a) the TOMS retrieval, (b) the model, and (c) the model including TOMS ozone data.
The main features between the model and the TOMS retrieval are well reproduced. The surface UV-E calculated by the model at low latitudes in Fig. 4b is lower than TOMS, while the model including TOMS ozone fields (Fig. 4c) slightly overestimates the surface UV-E in the same regions compared to the satellite retrieved UV-E doses.

The main uncertainties in the TOMS retrieval are related to clouds (Krotkov et al., 2001) and aerosols (Arola et al., 2005; Krotkov et al., 1998). Bais et al. (2007) emphasize the importance of including absorbing aerosols in the satellite derived UV-E estimates and that the overestimation is probably related to aerosols. Fioletov et al. (2002) found an overestimation of $10 \%$ on average at 9 sites in Canada. The biases can be seen under clear sky conditions and in the non absorbing ozone bands which indicate that air pollution and aerosols are most likely responsible for the overestimation in TOMS. UV measurements at 4 sites in USA provide an average positive bias of 5\% compared to TOMS (Sabburg et al., 2002). 

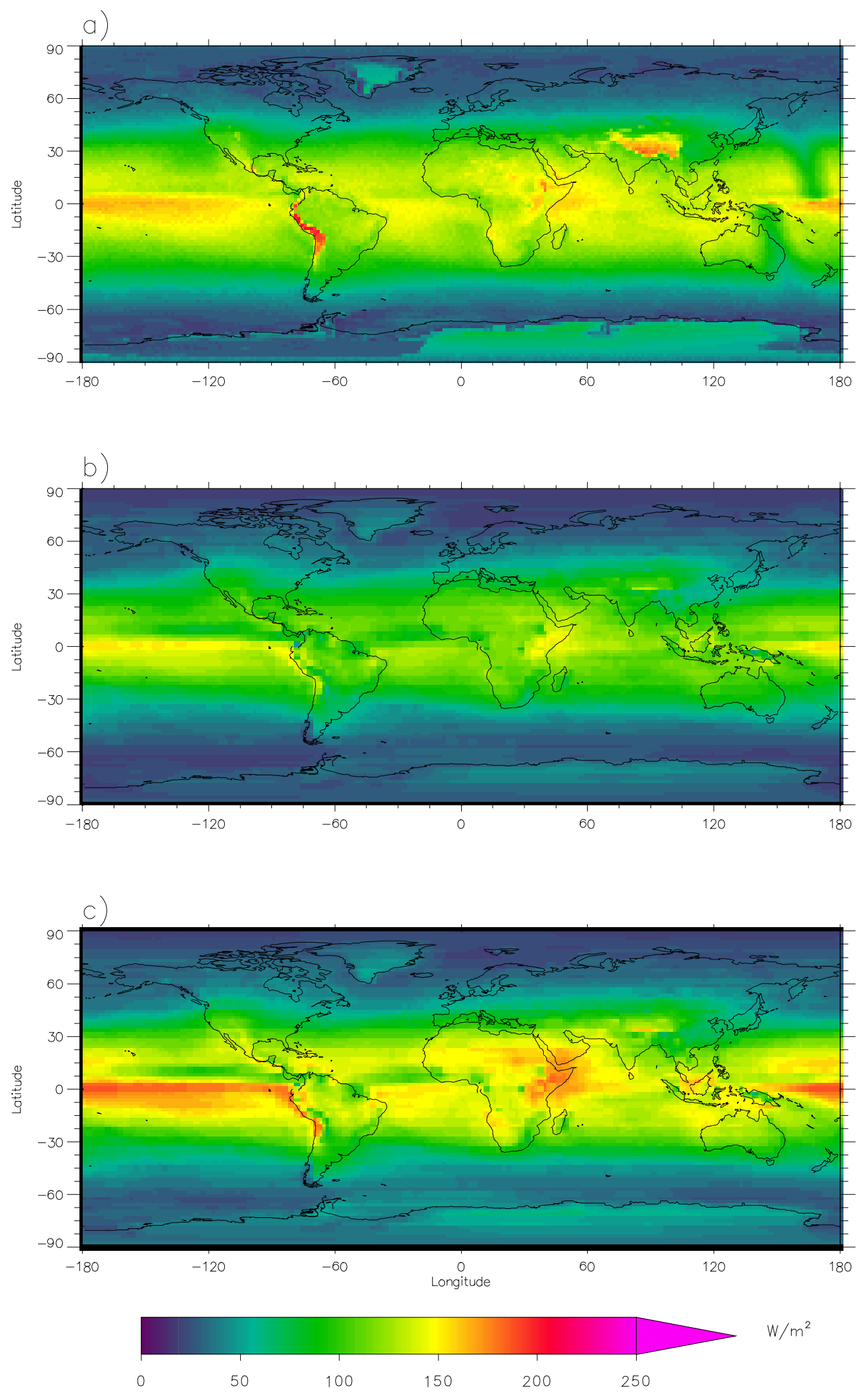

Fig. 4. Annual UV-E doses at the surface in year 2000 from (a) TOMS, (b) the model, and (c) the model including ozone data from TOMS. 

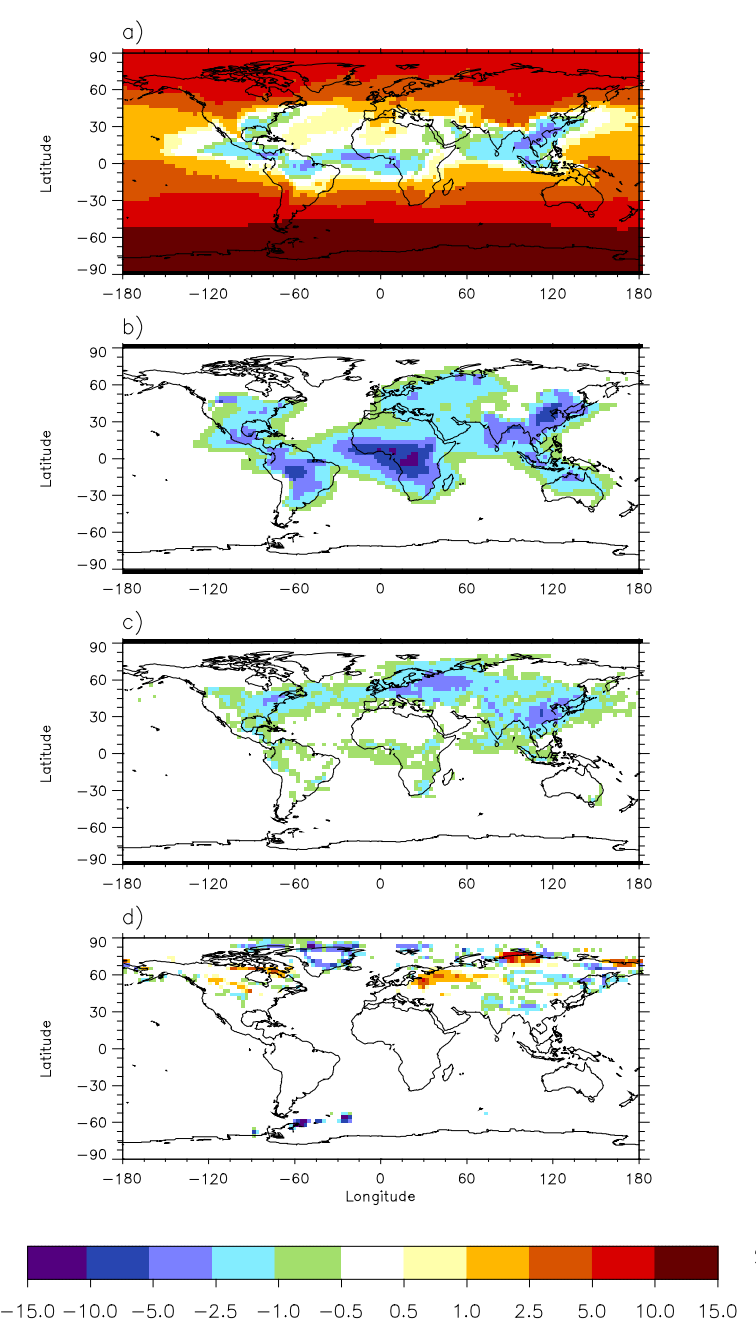
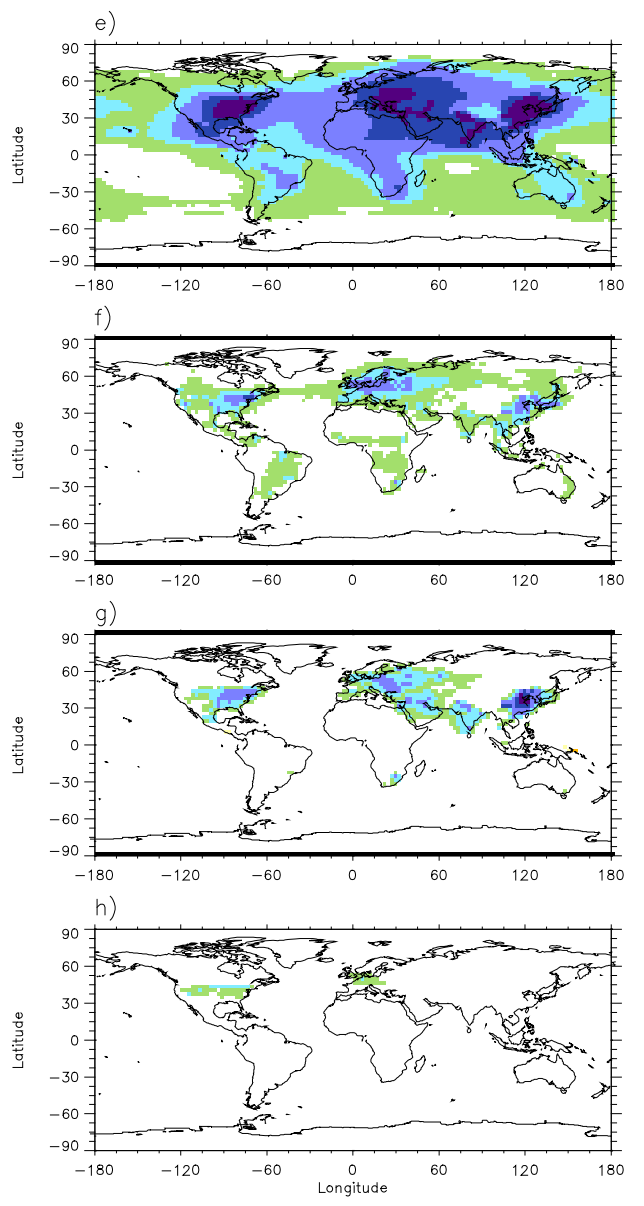

$\%$

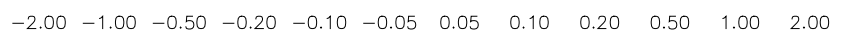

Fig. 5. Percentage change in model estimated annual mean UV-E at the surface since 1750. The UV-E changes are due to (a) ozone (both tropospheric and stratospheric), (b) carbonaceous aerosols, (c) cloud albedo effect (first indirect effect) of aerosols, (d) surface albedo, (e) sulphate aerosols, (f) $\mathrm{NO}_{2}$, (g) $\mathrm{SO}_{2}$, and (h) aviation induced contrails and cirrus. Note the different color scale for the left and right panels.

Corrections of TOMS derived UV-E for absorbing aerosols have found to reduce the observed biases (Cede et al., 2004). Furthermore, without corrections, Arola et al. (2005) found an overestimation of TOMS UV-E compared to ground based measurements surface UV-E doses at Thessaloniki, Greece and Ispra, Italy of $19.2 \%$ and $29.7 \%$, respectively. This was reduced to no bias, and a small underestimation $(-1.4 \%)$, respectively, when a correction for absorbing aerosols was taken into account (Arola et al., 2005).

\section{Results}

Figure 5 shows the percentage change in annual mean surface UV-E for the different mechanisms investigated. The simulations show that ozone depletion in the stratosphere has increased mid- and high latitude UV-E at the surface, with the highest changes (up to 22\%) over Antarctica (see Fig. 5a). The reduction of stratospheric ozone has increased UV-E by around $10 \%$, while increased levels of tropospheric ozone have reduced UV-E by $5-10 \%$ in the NH over the industrial era. Between approximately $30^{\circ} \mathrm{S}-30^{\circ} \mathrm{N}$, UV-E is reduced due to higher concentrations of ozone in the troposphere. Separate figures for tropospheric and stratospheric ozone change are shown in Fig. 6. The sum of stratospheric and tropospheric ozone changes result in a $4 \%$ global increase of UV-E at the surface. This is consistent with a previous study which reported a significant increase of UV-E at high latitudes of greater than $20 \%$ and a decrease at lower latitudes of a few percent (Sabziparvar et al., 1998).

The impacts of the changes in the direct effect of aerosols on the incoming UV-E radiation since 1750 are presented in Fig. $5 b$ and e (carbonaceous and sulphate aerosols, respectively). Carbonaceous aerosols include organic carbon 

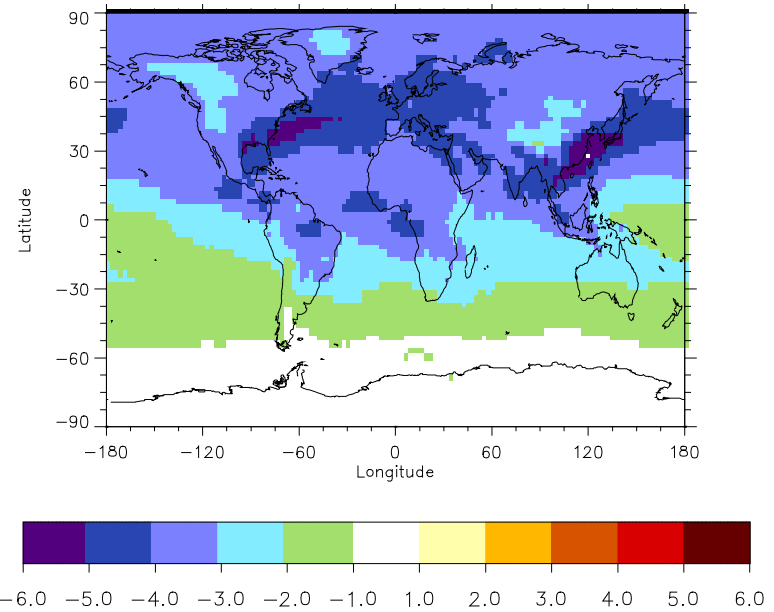

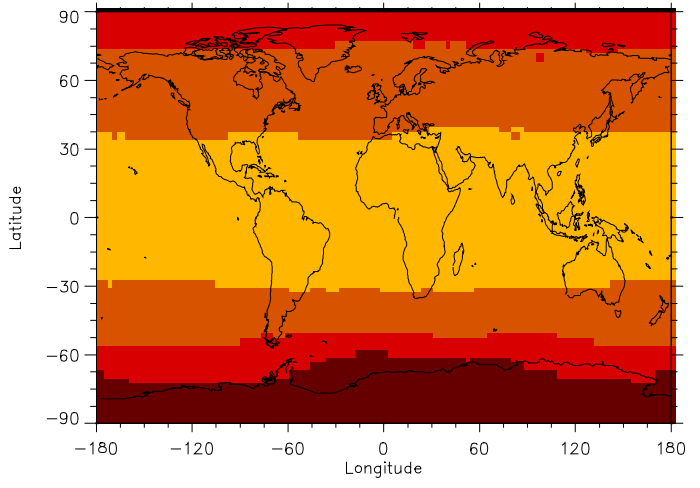

$\%$

$-20.0-15.0-10.0-5.0 \quad-2.5 \quad-1.0 \quad 1.0 \quad 2.5 \quad 5.0 \quad 10.0 \quad 15.0 \quad 20.0$

Fig. 6. Tropospheric and Stratospheric ozone changes. Annual changes of surface UV-E in percent due to exclusively tropospheric ozone (left) and stratospheric ozone (right).
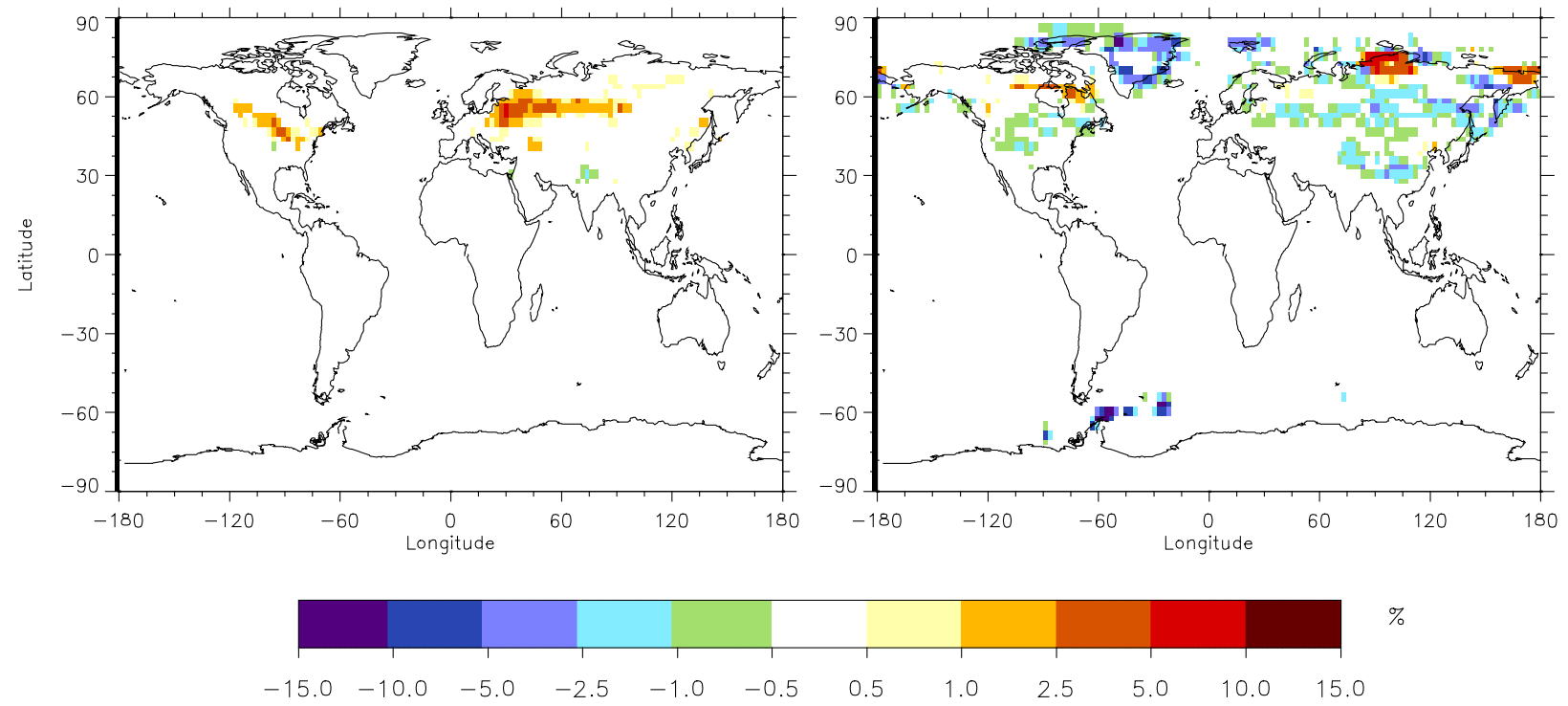

Fig. 7. Land use and snow cover change. Annual changes of surface UV-E in percent due to surface albedo change (left) and snow cover changes (right).

and black carbon (soot) from both fossil fuel and biomass burning. These aerosols both scatter and absorb UV radiation and cause a strong reduction in the UV-E dose in Central Africa due to biomass burning. Here, the UV-E reduction has a maximum of $12 \%$, located in the center of the biomass burning area. Sulphate aerosols contribute to UV-E dimming by pure scattering, particularly over the continents in mid latitudes of the NH. The largest reductions occur in North East America, Eastern Europe, and South East Asia, with a reduction in surface UV-E of $2-3 \%$.

The cloud albedo effect, also called the first indirect aerosol effect, denotes an increasing fraction of reflected solar radiation caused by a reduced effective radius of the cloud water droplets. The cloud albedo effect reduces the UV-E up to $5 \%$ in the same regions where the direct aerosol effect has the strongest impact (see Fig. 5c).

Anthropogenic changes in land use, specifically deforestation for agricultural purposes, also influence surface UV changes because of the much higher surface albedo of snowcovered agricultural land than forest (Betts, 2000). On the other hand, the reduction of snow cover since 1750 due to a warmer climate results in a reduced surface albedo. Figure $5 \mathrm{~d}$ shows the UV-E change caused by the surface albedo change related to both snow cover and land use. Separate figures for snow cover and land use changes are shown in Fig. 7. In Eurasia, North America and East Asia, the increase in the 

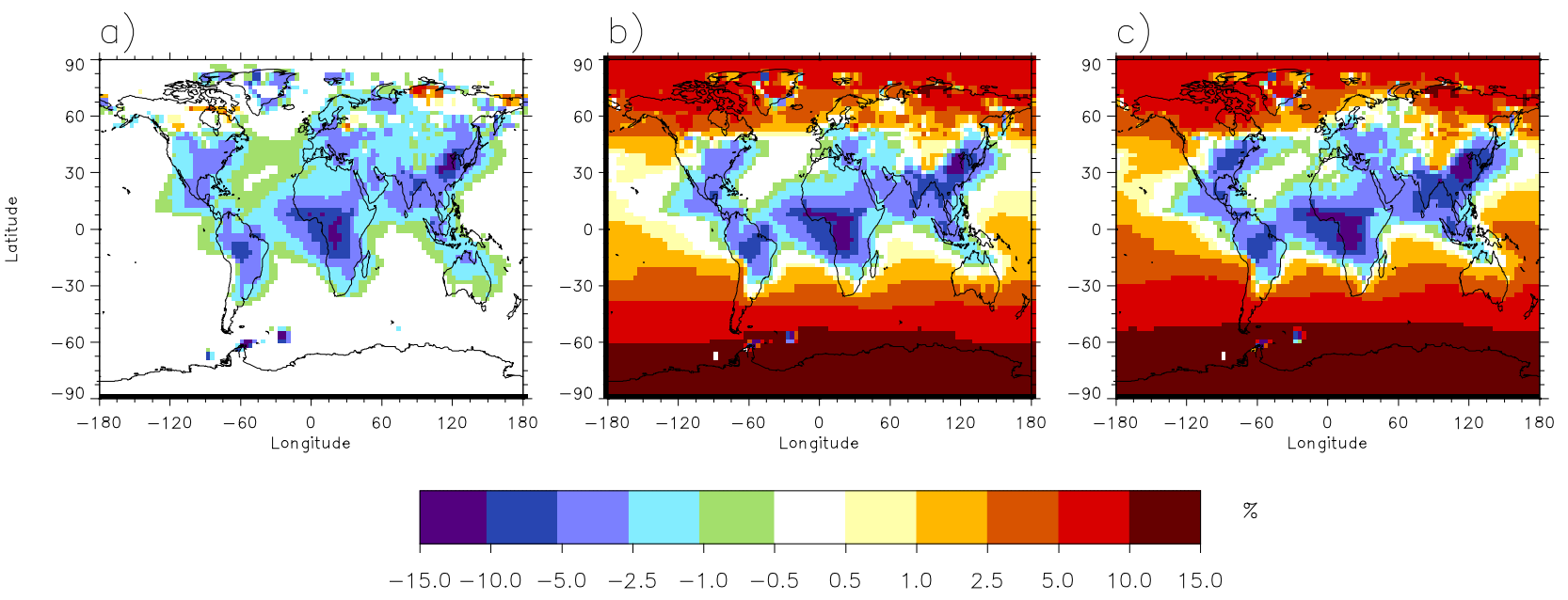

Fig. 8. Percentage changes in model estimated annual mean surface UV are shown for (a) UVA, (b) UVB and (c) UV-E radiation since pre industrial time (1750-2000).

surface albedo caused by land use are largest (Hansen et al., 2005; Myhre et al., 2005) and hence the strongest increase in surface UV-E is seen in these regions. The surface albedo raises the annual mean UV-E radiation up to 5\% in regions with widespread land use. The reduced snow cover in regions in mid to high latitudes reduces the annual surface UV-E by $1-2 \%$ over land. The radiative effect of snow cover change is small because the snow albedo change occurs mostly during winter months when the insolation and exposure of UV radiation is small. The annual average is therefore more dominated by the summer months.

UV-E changes as a response to changes in the trace gases $\mathrm{NO}_{2}$ and $\mathrm{SO}_{2}$ are presented in Fig. 5f and g, respectively. $\mathrm{NO}_{2}$ and $\mathrm{SO}_{2}$ are not only precursors of ozone and sulphate aerosols, respectively; they are also absorbers of UVradiation and contribute directly to the reduction of UV-E at the surface. The UV-E reduction shown in Fig. $5 \mathrm{f}$ is strongest near the source of $\mathrm{NO}_{2}$ emissions, i.e. in North America, Europe, and Asia, with a maximum reduction of $1.5 \%$ in North East America. $\mathrm{SO}_{2}$ absorbs only in the UVB part of the spectrum, but reduces the UV-E dose at the surface as strongly as $\mathrm{NO}_{2}$ and even stronger in some regions; see Fig. $5 \mathrm{~g}$. In South East Asia, the UV-E dose has decreased by $1.5 \%$.

Contrails and aviation-induced cirrus clouds are only minor contributors to the UV-E changes at the surface (Fig. 5h), with a maximum reduction of less than $0.5 \%$ in regions with dense air traffic.

Figure $8 \mathrm{a}-\mathrm{c}$ shows UV changes at the surface caused by all the mechanisms described above, but separated for UVA, UVB, and UV-E radiation, respectively. Only at high latitudes, most strongly in the $\mathrm{SH}$, a net increase of surface UVB radiation is present due to reduced stratospheric ozone. Carbonaceous aerosols are particularly effective in blocking UV radiation, as these aerosols both absorb and scatter UV radiation. Carbonaceous aerosols are responsible for the greatest reductions, detected in Central Africa and South East Asia for all UV-bands. There is a strong land signature in all three UV spectra due to anthropogenic emissions of shortlived aerosols and gases. The changes in UVB and UV-E at the surface are similar because the CIE-weights are highest for the shortest wavelengths. The relatively large difference between UVA and UVB is explained by the smaller ozone absorption in the former band. Figure 8 shows a reduction in the surface UV at most land areas over the industrial era, with the largest reduction in many of the most populated regions.

\section{Summary and conclusions}

Based on our simulations, we argue that $\mathrm{SO}_{2}, \mathrm{NO}_{2}$, ozone, and direct and indirect effects of aerosols have reduced surface UV-E by up to $15-20 \%$, during the industrial era. The strongest reduction is seen over South East Asia, Europe and North America. It has previously been indicated that pollutants could mask expected increase of UV from stratospheric ozone depletion, especially through absorption of black carbon over urban areas (Barnard et al., 2003). Here, we show that this has occurred over most land regions through the time period 1750-2000. This UV-dimming has similarities with the dimming of total solar radiation at the surface (Alpert et al., 2005; Kvalevåg and Myhre, 2007; Liepert, 2002; Stanhill and Cohen, 2001). Even though the dimming of the total solar radiation has been variable since the first observations in 1950s, it has been dominating over the period with measurements.

Long term changes in cloud cover and the causes of the changes are highly uncertain. Natural variability in clouds is large, but cloud cover changes from increased cloud lifetime due to anthropogenic aerosols have also been suggested (Albrecht, 1989). Reduced cloud cover due to the semi-direct 
aerosol effect (Ackerman et al., 2000) in addition to feedbacks from of global warming may have influenced cloud cover over longer time periods. Koren et al. (2008) indicate by an analytical method and Moderate Resolution Imaging Spectroradiometer (MODIS) satellite data that cloud cover changes depend both on the aerosols content and the amount of absorbing aerosols. An increase in the cloud cover would reduce the surface UV-E radiation and vice versa for a decrease in cloud cover.

As described above most of the observations the last 2-3 decades of surface UV-E radiation show an increase, especially in the NH. In contrast, our model results show a decrease over land regions the last 250 years. The only significant component included in the model that increases the surface UV-E radiation over the time period $1750-2000$ is the reduction in stratospheric ozone. The decline in stratospheric ozone has occurred only over the last 3-4 decades. In addition, some aerosol components decreasing surface UV-E radiation during most of the industrial era have been reduced the last decades in certain regions and could thus also have contributed to an increase in the surface UV-E radiation.

The implication of this study is that future changes in UV radiation clearly depend on a complex mixture of factors, among them ozone and atmospheric pollutants. This links health, UV radiation, air pollution, and climate change.

Acknowledgements. UV observations from 9 sites were obtained from the World Ozone and Ultraviolet Radiation Data Centre (WOUDC) operated by Environment Canada, Toronto, Canada under the auspices of the World Meteorological Organization. The authors acknowledge WOUDC for their effort in maintaining this WMO data center. The following data providers to the WOUDC are acknowledged: Japan Meteorological Agency for the data from Sapporo, Tateno/Tsukuba, and Naha; The Central Weather Bureau of Taiwan for the data from Chengkung; The Meteorological Service of Canada for the data from Mauna Loa, Toronto, Montreal and Halifax; The Slovak HydroMeteorological Institute for the data from Poprad-Ganovce. The Norwegian institute for Air Research hosts the Norwegian UV observations and performs the measurements in Oslo, Andøya and $\mathrm{Ny}$-Ålesund with support from the Norwegian Pollution Control Authority. We thank Arne Dahlback, University of Oslo, for the maintenance of the UV measurements in Oslo. We also thank the Norwegian Radiation Protection Authority for performing the UV observations in Bergen and Trondheim.

Edited by: K. Lehtinen

\section{References}

Ackerman, A. S., Toon, O. B., Stevens, D. E., Heymsfield, A. J., Ramanathan, V., and Welton, E. J.: Reduction of tropical cloudiness by soot, Science, 288, 1042-1047, 2000.

Albrecht, B. A.: Aerosols, Cloud Microphysics, and Fractional Cloudiness, Science, 245, 1227-1230, 1989.

Alpert, P., Kishcha, P., Kaufman, Y. J., and Schwarzbard, R.: Global dimming or local dimming? Effect of urbanization on sunlight availability, Geophys. Res. Lett., 32, L17802, doi:10.1029/2005GL023320, 2005

Arola, A., Kazadzis, S., Krotkov, N., Bais, A., Grobner, J., and Herman, J. R.: Assessment of TOMS UV bias due to absorbing aerosols, J. Geophys. Res.-Atmos., 110, D23211, doi:10.1029/2005JD005913, 2005.

Bais, A. F., Lubin, D., Arola, A., Bernhard, G., Blumthaler, M., Chubarova, N., Erlick, C., Gies, H. P., Krotkov, N., Lantz, K., Mayer, B., McKenzie, R. L., Piacentini, R. D., Seckmeyer, G., Slusser, J. R., and Zerefos, C. S.: Surface Ultraviolet Radiation: Past, Present, and Future, Chapter 7 in Scientific Assessment of Ozone Depletion: 2006, Global Ozone Research and Monitoring Project, Report No 50, 2007.

Barnard, J. C., Volkamer, R., and Kassianov, E. I.: Estimation of the mass absorption cross section of the organic carbon component of aerosols in the Mexico City Metropolitan Area, Atmos. Chem. Phys., 8, 6665-6679, 2008, http://www.atmos-chem-phys.net/8/6665/2008/.

Barnard, W. F., Saxena, V. K., Wenny, B. N., and DeLuisi, J. J.: Daily surface UV exposure and its relationship to surface pollutant measurements, J. Air Waste Manage, 53, 237-245, 2003.

Betts, R. A.: Offset of the potential carbon sink from boreal forestation by decreases in surface albedo, Nature, 408, 187-190, 2000.

Borkowski, J. L.: Modelling of UV radiation variations at different time scales, Ann. Geophys., 26, 441-446, 2008, http://www.ann-geophys.net/26/441/2008/.

Cede, A., Luccini, E., Nunez, L., Piacentini, R. D., Blumthaler, M., and Herman, J. R.: TOMS-derived erythemal irradiance versus measurements at the stations of the Argentine UV Monitoring Network, J. Geophys. Res.-Atmos., 109, D08109, doi:10.1029/2004JD004519, 2004.

Chubarova, N. Y.: UV variability in Moscow according to longterm UV measurements and reconstruction model, Atmos. Chem. Phys., 8, 3025-3031, 2008, http://www.atmos-chem-phys.net/8/3025/2008/.

Chubarova, N. Y. and Nezval, Y. I.: Thirty year variability of UV irradiance in Moscow, J. Geophys. Res.-Atmos., 105, 12529_ 12539, 2000

Clerbaux, C., Cunnold, D. M., Anderson, J., Engel, A., Fraser, P. J., Mahieu, E., Manning, A., Miller, J., Montzka, S. A., Nassar, R., Prinn, R., Reimann, S., Rinsland, C. P., Simmonds, P., Verdonik, D., Weiss, R., Wuebbles, D., and Yokouchi, Y.: Long-Lived Compounds, Chapter 1 in Scientific Assessment of Ozone Depletion: 2006, Global Ozone Research and Monitoring Project, Report No 50, 2007.

Collins, W. D., Bitz, C. M., Blackmon, M. L., Bonan, G. B., Bretherton, C. S., Carton, J. A., Chang, P., Doney, S. C., Hack, J. J., Henderson, T. B., Kiehl, J. T., Large, W. G., McKenna, D. S., Santer, B. D., and Smith, R. D.: The Community Climate System Model version 3 (CCSM3), J. Climate, 19, 2122-2143, doi:10.1175/JCLI3761.1, 2006.

den Outer, P. N., Slaper, H., and Tax, R. B.: UV radiation in the Netherlands: Assessing long-term variability and trends in relation to ozone and clouds, J. Geophys. Res.-Atmos., 110, D02203, doi:10.1029/2004JD004824, 2005.

Dinar, E., Riziq, A. A., Spindler, C., Erlick, C., Kiss, G., and Rudich, Y.: The complex refractive index of atmospheric and model humic-like substances (HULIS) retrieved by a cavity ring down aerosol spectrometer (CRD-AS), Conference on 
Spectroscopy and Dynamics of Microparticles, Bristol, England, ISI:000250173900018, 279-295, 2007.

Engelsen, O., Hansen, G. H., and Svenoe, T.: Long-term (19362003) ultraviolet and photosynthetically active radiation doses at a north Norwegian location in spring on the basis of total ozone and cloud cover, Geophys. Res. Lett., 31, L12103, doi:10.1029/2003GL019241, 2004.

Feister, U., Junk, J., Woldt, M., Bais, A., Helbig, A., Janouch, M., Josefsson, W., Kazantzidis, A., Lindfors, A., den Outer, P. N., and Slaper, H.: Long-term solar UV radiation reconstructed by ANN modelling with emphasis on spatial characteristics of input data, Atmos. Chem. Phys., 8, 3107-3118, 2008, http://www.atmos-chem-phys.net/8/3107/2008/

Fioletov, V. E., Kerr, J. B., Wardle, D. I., Krotkov, N., and Herman, J. R.: Comparison of Brewer ultraviolet irradiance measurements with total ozone mapping spectrometer satellite retrievals, Opt. Eng., 41, 3051-3061, 2002.

Fioletov, V. E., McArthur, L. J. B., Kerr, J. B., and Wardle, D. I.: Long-term variations of UV-B irradiance over Canada estimated from Brewer observations and derived from ozone and pyranometer measurements, J. Geophys. Res.-Atmos., 106, 2300923027, 2001.

Fitzgerald, J. W.: Approximation formulas for equlibrium size of an aerosol particle as a function of its dry size and composition and ambient relative humidity, J. Appl. Meteorol., 14, 1044-1049, 1975.

Forster, P., Ramaswamy, V., Artaxo, P., Berntsen, T., Betts, R., Fahey, D. W., Haywood, J., Lean, J., Lowe, D. C., Myhre, G., Nganga, J., Prinn, R., Raga, G., Schulz, M., and Dorland, R. V.: Changes in Atmospheric Constituents and in Radiative Forcing, in: Climate Change 2007: The Physical Science Basis, Contribution of Working Group I to the Fourth Assessment Report of the Intergovernmental Panel on Climate Change, 129-234, 2007.

Gauss, M., Myhre, G., Isaksen, I. S. A., Grewe, V., Pitari, G., Wild, O., Collins, W. J., Dentener, F. J., Ellingsen, K., Gohar, L. K., Hauglustaine, D. A., Iachetti, D., Lamarque, F., Mancini, E., Mickley, L. J., Prather, M. J., Pyle, J. A., Sanderson, M. G., Shine, K. P., Stevenson, D. S., Sudo, K., Szopa, S., and Zeng, G.: Radiative forcing since preindustrial times due to ozone change in the troposphere and the lower stratosphere, Atmos. Chem. Phys., 6, 575-599, 2006, http://www.atmos-chem-phys.net/6/575/2006/.

Glandorf, M., Arola, A., Bais, A., and Seckmeyer, G.: Possibilities to detect trends in spectral UV irradiance, Theor. Appl. Climatol., 81, 33-44, 2005.

Hansen, J., Sato, M., Ruedy, R., Nazarenko, L., Lacis, A., Schmidt, G. A., Russell, G., Aleinov, I., Bauer, M., Bauer, S., Bell, N., Cairns, B., Canuto, V., Chandler, M., Cheng, Y., Del Genio, A., Faluvegi, G., Fleming, E., Friend, A., Hall, T., Jackman, C., Kelley, M., Kiang, N., Koch, D., Lean, J., Lerner, J., Lo, K., Menon, S., Miller, R., Minnis, P., Novakov, T., Oinas, V., Perlwitz, J., Perlwitz, J., Rind, D., Romanou, A., Shindell, D., Stone, P., Sun, S., Tausnev, N., Thresher, D., Wielicki, B., Wong, T., Yao, M., and Zhang, S.: Efficacy of climate forcings, J. Geophys. Res.Atmos., 110, D18104, doi:10.1029/2005JD005776, 2005.

Haywood, J. M., Osborne, S. R., Francis, P. N., Keil, A., Formenti, P., Andreae, M. O., and Kaye, P. H.: The mean physical and optical properties of regional haze dominated by biomass burning aerosol measured from the C-130 aircraft during SAFARI 2000, J. Geophys. Res.-Atmos., 108, 8473, doi:10.1029/2002jd002226, 2003.

Herman, J. R., Krotkov, N., Celarier, E., Larko, D., and Labow, G.: Distribution of UV radiation at the Earth's surface from TOMSmeasured UV-backscattered radiances, J. Geophys. Res.-Atmos. 104, 12059-12076, 1999.

Jaroslawski, J. P. and Krzyscin, J. W.: Importance of aerosol variations for surface UV-B level: Analysis of ground-based data taken at Belsk, Poland, 1992-2004, J. Geophys. Res.-Atmos., 110, D16201, doi:10.1029/2005JD005951, 2005.

Josefsson, W.: UV-radiation 1983-2003 measured at Norrkoping, Sweden, Theor. Appl. Climatol., 83, 59-76, 2006.

Junk, J., Feister, U., and Helbig, A.: Reconstruction of daily solar UV irradiation from 1893 to 2002 in Potsdam, Germany, Int. J. Biometeorol., 51, 505-512, 2007.

Kanakidou, M., Seinfeld, J. H., Pandis, S. N., Barnes, I., Dentener, F. J., Facchini, M. C., Van Dingenen, R., Ervens, B., Nenes, A., Nielsen, C. J., Swietlicki, E., Putaud, J. P., Balkanski, Y., Fuzzi, S., Horth, J., Moortgat, G. K., Winterhalter, R., Myhre, C. E. L., Tsigaridis, K., Vignati, E., Stephanou, E. G., and Wilson, J.: Organic aerosol and global climate modelling: a review, Atmos. Chem. Phys., 5, 1053-1123, 2005, http://www.atmos-chem-phys.net/5/1053/2005/.

Kazantzidis, A., Bais, A. F., Grobner, J., Herman, J. R., Kazadzis, S., Krotkov, N., Kyro, E., den Outer, P. N., Garane, K., Gorts, P., Lakkala, K., Meleti, C., Slaper, H., Tax, R. B., Turunen, T., and Zerefos, C. S.: Comparison of satellitederived UV irradiances with ground-based measurements at four European stations, J. Geophys. Res.-Atmos., 111, D13207, doi:10.1029/2005JD006672, 2006.

Kirchstetter, T. W., Novakov, T., and Hobbs, P. V.: Evidence that the spectral dependence of light absorption by aerosols is affected by organic carbon, J. Geophys. Res.-Atmos., 109, D21208, doi:10.1029/2004jd004999, 2004.

Koren, I., Martins, J. V., Remer, L. A., and Afargan, H.: Smoke invigoration versus inhibition of clouds over the Amazon, Science, 321, 946-949, 2008.

Krotkov, N. A., Bhartia, P. K., Herman, J. R., Fioletov, V., and Kerr, J.: Satellite estimation of spectral surface UV irradiance in the presence of tropospheric aerosols 1. Cloud-free case, J. Geophys. Res.-Atmos., 103, 8779-8793, 1998.

Krotkov, N. A., Herman, J. R., Bhartia, P. K., Fioletov, V., and Ahmad, Z.: Satellite estimation of spectral surface UV irradiance 2, Effects of homogeneous clouds and snow, J. Geophys. Res.-Atmos., 106, 11743-11759, 2001.

Krzyscin, J. W., Eerme, K., and Janouch, M.: Long-term variations of the UV-B radiation over Central Europe as derived from the reconstructed UV time series, Ann. Geophys., 22, 1473-1485, 2004, http://www.ann-geophys.net/22/1473/2004/.

Kvalevåg, M. M. and Myhre, G.: Human impact on direct and diffuse solar radiation during the industrial era, J. Climate, 20, 4874-4883, doi:10.1175/JCLI4277.1, 2007.

Lakkala, K., Kyro, E., and Turunen, T.: Spectral UV measurements at Sodankyla during 1990-2001, J. Geophys. Res.-Atmos., 108, 4621, doi:10.1029/2002JD003300, 2003.

Liepert, B. G.: Observed reductions of surface solar radiation at sites in the United States and worldwide from 1961 to 1990, Geophys. Res. Lett., 29, 1421, doi:10.1029/2002GL014910, 2002. 
Lindfors, A. and Vuilleumier, L.: Erythemal UV at Davos (Switzerland), 1926-2003, estimated using total ozone, sunshine duration, and snow depth, J. Geophys. Res.-Atmos., 110, D02104, doi:10.1029/2004JD005231, 2005.

Liu, S. C., McKeen, S. A., and Madronich, S.: Effect of Anthropogenic Aerosols on Biologically-Active Ultraviolet-Radiation, Geophys. Res. Lett., 18, 2265-2268, 1991.

Martins J. V., Kaufman, Y. J., Castanho, A. D., and Remer, L. A.: Spectral absorption properties of aerosol particles from 350-2500 nm. Geophys. Res. Lett., 36, L13810, doi:10.1029/2009GL037435, 2009.

McKenzie, R. L., Aucamp, P. J., Bais, A. F., Bjorn, L. O., and Ilyas, M.: Changes in biologically-active ultraviolet radiation reaching the Earth's surface, Photochem. Photobiol., 6, 218-231, 2007.

McKenzie, R. L., Seckmeyer, G., Bais, A. F., Kerr, J. B., and Madronich, S.: Satellite retrievals of erythemal UV dose compared with ground-based measurements at northern and southern midlatitudes, J. Geophys. Res.-Atmos., 106, 24051-24062, 2001.

McKinlay, A. F. and Diffey, B. L.: A reference action spectrum for ultra-violet induced erythema in human skin, CIE Research Note, CIE-Journal, 6, 17-22, 1987.

Lund Myhre, C. E. and Nielsen, C. J.: Optical properties in the UV and visible spectral region of organic acids relevant to tropospheric aerosols, Atmos. Chem. Phys., 4, 1759-1769, 2004, http://www.atmos-chem-phys.net/4/1759/2004/.

Myhre, G., Bellouin, N., Berglen, T. F., Berntsen, T. K., Boucher, O., Grini, A., Isaksen, I. S. A., Johnsrud, M., Mishchenko, M. I., Stordal, F., and Tanre, D.: Comparison of the radiative properties and direct radiative effect of aerosols from a global aerosol model and remote sensing data over ocean, Tellus B, 59, 115129, doi:10.1111/j.1600-0889.2006.00226.x, 2007.

Myhre, G., Berntsen, T. K., Haywood, J. M., Sundet, J. K., Holben, B. N., Johnsrud, M., and Stordal, F.: Modeling the solar radiative impact of aerosols from biomass burning during the Southern African Regional Science Initiative (SAFARI-2000) experiment, J. Geophys. Res.-Atmos., 108, 8501, doi:10.1029/2002jd002313, 2003.

Myhre, G., Jonson, J. E., Bartnicki, J., Stordal, F., and Shine, K. P.: Role of spatial and temporal variations in the computation of radiative forcing due to sulphate aerosols: A regional study, Q. J. Roy. Meteorol. Soc., 128, 973-989, doi:10.1256/0035900021643610, 2002.

Myhre, G., Kvalevåg, M. M., and Schaaf, C. B.: Radiative forcing due to anthropogenic vegetation change based on MODIS surface albedo data, Geophys. Res. Lett., 32, L21410, doi:10.1029/2005GL024004, 2005.

Myhre, G. and Stordal, F.: On the tradeoff of the solar and thermal infrared radiative impact of contrails, Geophys. Res. Lett., 28, 3119-3122, 2001.

Peng, C., Chan, M. N., and Chan, C. K.: The hygroscopic properties of dicarboxylic and multifunctional acids: Measurements and UNIFAC predictions, Environ. Sci. Technol., 35, 4495-4501, 2001.

Quaas, J. and Boucher, O.: Constraining the first aerosol indirect radiative forcing in the LMDZ GCM using POLDER and MODIS satellite data, Geophys. Res. Lett., 32, L17814, doi:10.1029/2005GL023850, 2005.

Quaas, J., Boucher, O., and Lohmann, U.: Constraining the total aerosol indirect effect in the LMDZ and ECHAM4 GCMs using MODIS satellite data, Atmos. Chem. Phys., 6, 947-955, 2006, http://www.atmos-chem-phys.net/6/947/2006/.

Ramankutty, N. and Foley, J. A.: Estimating historical changes in global land cover: Croplands from 1700 to 1992, Global Biogeochem. Cy., 13, 997-1027, 1999.

Sabburg, J., Rives, J. E., Meltzer, R. S., Taylor, T., Schmalzle, G., Zheng, S., Huang, N., Wilson, A., and Udelhofen, P. M.: Comparisons of corrected daily integrated erythemal UVR data from the US EPA/UGA network of Brewer spectroradiometers with model and TOMS-inferred data, J. Geophys. Res.-Atmos., 107, 4676, doi:10.1029/2001JD001565, 2002.

Sabziparvar, A. A., Forster, P. M. D., and Shine, E. P.: Changes in ultraviolet radiation due to stratospheric and tropospheric ozone changes since preindustrial times, J. Geophys. Res.-Atmos., 103, 26107-26113, 1998.

Sasaki, M., Takeshita, S., Oyanagi, T., Miyake, Y., and Sakata, T.: Increasing trend of biologically active solar ultraviolet-B irradiance in mid-latitude Japan in the 1990s, Opt. Eng., 41, 30623069, 2002.

Sausen, R., Isaksen, I., Grewe, V., Hauglustaine, D., Lee, D. S., Myhre, G., Kohler, M. O., Pitari, G., Schumann, U., Stordal, F., and Zerefos, C.: Aviation radiative forcing in 2000: An update on IPCC (1999), Meteorol. Z., 14, 555-561, 2005.

Schulz, M., Textor, C., Kinne, S., Balkanski, Y., Bauer, S., Berntsen, T., Berglen, T., Boucher, O., Dentener, F., Guibert, S., Isaksen, I. S. A., Iversen, T., Koch, D., Kirkevåg, A., Liu, X., Montanaro, V., Myhre, G., Penner, J. E., Pitari, G., Reddy, S., Seland, Ø., Stier, P., and Takemura, T.: Radiative forcing by aerosols as derived from the AeroCom present-day and pre-industrial simulations, Atmos. Chem. Phys., 6, 5225-5246, 2006 ,

http://www.atmos-chem-phys.net/6/5225/2006/.

Stamnes, K., Tsay, S. C., Wiscombe, W., and Jayaweera, K.: Numerically Stable Algorithm for Discrete-Ordinate-Method Radiative-Transfer in Multiple-Scattering and Emitting Layered Media, Appl. Optics, 27, 2502-2509, 1988.

Stanhill, G. and Cohen, S.: Global dimming: a review of the evidence for a widespread and significant reduction in global radiation with discussion of its probable causes and possible agricultural consequences, Agr. Forest Meteorol., 107, 255-278, 2001.

Stordal, F., Myhre, G., Stordal, E. J. G., Rossow, W. B., Lee, D. S., Arlander, D. W., and Svendby, T.: Is there a trend in cirrus cloud cover due to aircraft traffic?, Atmos. Chem. Phys., 5, 2155-2162, 2005 ,

http://www.atmos-chem-phys.net/5/2155/2005/.

Sun H. and Bond, T. C.: Color of brown carbon: A model for ultraviolet and visible light absorption by organic carbon aerosol, Geophys. Res. Lett., 34, L17813, doi:10.1029/2007GL029797, 2007.

Textor, C., Schulz, M., Guibert, S., Kinne, S., Balkanski, Y., Bauer, S., Berntsen, T., Berglen, T., Boucher, O., Chin, M., Dentener, F., Diehl, T., Easter, R., Feichter, H., Fillmore, D., Ghan, S., Ginoux, P., Gong, S., Grini, A., Hendricks, J., Horowitz, L., Huang, P., Isaksen, I., Iversen, I., Kloster, S., Koch, D., Kirkevåg, A., Kristjansson, J. E., Krol, M., Lauer, A., Lamarque, J. F., Liu, X., Montanaro, V., Myhre, G., Penner, J., Pitari, G., Reddy, S., Seland, Ø., Stier, P., Takemura, T., and Tie, X.: Analysis and quantification of the diversities of aerosol life cycles within Ae- 
roCom, Atmos. Chem. Phys., 6, 1777-1813, 2006,

http://www.atmos-chem-phys.net/6/1777/2006/.

Toon, O. B., Pollack, J. B., and Khare, B. N.: Optical-constants of several atmospheric aerosol species - Ammonium-Sulfate, Aluminum-Oxide, and Sodium-Chloride, J. Geophys. Res.-Oc. Atm., 81, 5733-5748, 1976.
Trepte, S. and Winkler, P.: Reconstruction of erythemal UV irradiance and dose at Hohenpeissenberg (1968-2001) considering trends of total ozone, cloudiness and turbidity, Theor. Appl. Climatol., 77, 159-171, doi:10.1007/s00704-004-0034-y, 2004.

WCP: A Preliminary Cloudless Standard Atmosphere for Radiation Computation (World Climate Program), WMO, Geneva, 1986. 